\title{
Digestible tryptophan:lysine ratio for laying hens
}

\section{Matheus Ramalho de Lima ${ }^{1}$, Fernando Guilherme Perazzo Costa1, Ricardo Romão Guerra1, José Humberto Vilar da Silva², Carlos Bôa-Viagem Rabello', Maria Angelica Miglino³ ${ }^{3}$ Eduardo Terra Nogueira ${ }^{4}$, Sarah Gomes Pinheiro ${ }^{1}$}

\footnotetext{
${ }^{1}$ Universidade Federal da Paraiba, Departamento de Zootecnia, PB 079, km 12, 58397000, Campus II, Areia, Paraiba, Brazil.

2 Universidade Federal da Paraiba, Departamento de Zootecnia, Campus III, Bananeiras, Paraiba, Brazil.

${ }^{3}$ Universidade de São Paulo, FMVZ/USP. São Paulo, Brazil.

${ }^{4}$ Ajinomoto Biolatina Industria e Comercio Ltda.
}

\begin{abstract}
The objective of this study was to evaluate the requirement of digestible tryptophan for white laying hens in the production stage fed diets of different digestible tryptophan:digestible lysine ratios, as well as animal performance and histological alterations in their reproductive and digestive systems. A total of 280 white laying hens at 29 weeks of age were distributed in a completely randomized design with five treatments and seven replications with eight birds in each. The treatments consisted of a base feed, formulated with corn, soybean meal and corn gluten meal, and supplemented with the synthetic amino acids L-lysine, DL-methionine, L-threonine, L-isoleucine, L-arginine, and L-valine, so as to meet the nutritional requirements for laying hens, except for digestible tryptophan. The basal diet was supplemented with $0.00 ; 0.017$; $0.035 ; 0.052$; and $0.069 \mathrm{~g} / \mathrm{kg}$ of L-tryptophan in substitution for corn starch with the objective of reaching the levels of 0.151 ; $0.167 ; 0.183 ; 0.199$; and $0.215 \mathrm{~g} / \mathrm{kg}$ of digestible tryptophan in the feed. For the ratio between digestible amino acids and lysine, the recommendation of Brazilian Tables for Poultry and Swine was followed, except for the digestible tryptophan: digestible lysine ratios, which were 19,21, 23, 25 and 27 for each treatment. The variation in the digestible tryptophan: digestible lysine ratio promoted changes in performance and in the histological characteristics, improving the results. The digestible tryptophan:digestible lysine ratio of $24.5 \%$ in the feed of white laying hens in production stage promotes better animal performance and histological results.
\end{abstract}

Key Words: egg production, histological effects, poultry industry

\section{Introduction}

According to Peganova \& Eder (2003) and Deponti et al. (2007), tryptophan is significant in the formulation of feeds with a reduced content of protein in the nutrition of laying hens because it is considered the third limiting amino acid. L-tryptophan $98 \%$ is produced by the fermentation of raw materials of agricultural origin, such as beet molasses or hydrolyzed starch. It consists of white and light yellow crystals with 98\% tryptophan and 100\% digestibility (Ajinomoto, 2010).

Tryptophan is the forerunner of serotonin and melatonin syntheses, and reduces aggressiveness in birds, which, with no doubt, eases the daily management of the birds and, in a way, contributes to a more efficient egg production, since the number of damaged eggs is reduced in this situation. Tryptophan deficiency provokes a reduction in feed intake (Peganova \& Eder, 2002) and its requirement can be influenced by long-chain neutral amino acids present in the diet of laying hens, such as isoleucine, valine, leucine, phenylalanine, tyrosine, methionine and histidine, and even more by the protein in the diet.

Unlike the recommendations for lysine, tryptophan is usually evaluated based on the ratio with lysine, that is, aside from the individual levels of the amino acid, the ratio with lysine is currently one of the major allies of researchers in determining the best level of tryptophan. So, for birds in the laying stage, the recommendations are very diverse.

Thus, the objective of this study was to evaluate in animal performance parameters and histologically the requirement of digestible tryptophan for white laying hens in the production stage fed diets containing different ratios of digestible tryptophan:digestible lysine.

\section{Material and Methods}

The study was conducted at the Poultry Research Center of Universidade Federal da Paraiba (CCA/UFPB), according to ethical standards and approved by the Ethics Committee and the Biosafety Institute. A total of 280 white laying 
hens at 29 weeks of age were distributed in a completely randomized design, with five treatments, seven replications with eight birds each. The treatments consisted of a basal feed, formulated with corn, soybean meal and corn gluten meal, supplemented with industrial amino acids L-lysine, DL-methionine, L-threonine, L-isoleucine, L-arginine and L-valine so as to meet the nutritional requirements for laying hens, except for digestible tryptophan. The basal diet was supplemented with $0.00 ; 0.17 ; 0.35 ; 0.52$; and $0.69 \mathrm{~g} / \mathrm{kg}$ of L-tryptophan in substitution for corn starch with the objective of reaching levels of $1.51 ; 1.67 ; 1.83 ; 1.99$; and $2.15 \mathrm{~g} / \mathrm{kg}$ of digestible tryptophan in the feed (Table 1).

For the ratio between digestible amino acids and lysine, the recommendation of Rostagno et al. (2005) was followed, except for the digestible tryptophan:lysine ratios, which were 19, 21, 23, 25 and 27 for each treatment.
Potassium carbonate was included in the diet to meet the levels of potassium, owing to the reduction in the amount of soybean meal, which was limited by the need to cause lack of tryptophan in the basal diet. The L-glutamate acid was utilized to make the diets contain the same amount of protein. The dietary level of soybean oil and of the inert was balanced in substitution for acid L-glutamate, which was reduced with the increase of the levels of L-tryptophan in the experimental feed, to make the diets have not only the same amount of protein, but of energy as well.

The variables evaluated were: feed intake (g/bird/ day); egg production (egg/bird/day x 100); weight (g) and classification per egg type; egg mass (g/bird/day); mass conversion $(\mathrm{kg} / \mathrm{kg})$ and per egg dozen $(\mathrm{kg} / \mathrm{dz})$; weight (g) and percentage (\%) of yolk, albumen and shell; shell thickness (mm); Haugh unit and specific gravity.

Table 1 - Chemical and nutritional composition of the experimental diets

\begin{tabular}{|c|c|c|c|c|c|}
\hline \multirow{2}{*}{ Ingredient, $\mathrm{g} / \mathrm{kg}$} & \multicolumn{5}{|c|}{ Digestible tryptophan:lysine ratios, \% } \\
\hline & 19 & 21 & 23 & 25 & 27 \\
\hline$\overline{\text { Corn }}$ & 628.10 & 628.10 & 628.10 & 628.10 & 628.10 \\
\hline Soybean meal & 179.21 & 179.21 & 179.21 & 179.21 & 179.21 \\
\hline Limestone & 92.70 & 92.70 & 92.70 & 92.70 & 92.70 \\
\hline Dicalcium phosphate & 15.42 & 15.42 & 15.42 & 15.42 & 15.42 \\
\hline Salt & 4.88 & 4.88 & 4.88 & 4.88 & 4.88 \\
\hline L-threonine & 0.36 & 0.36 & 0.36 & 0.36 & 0.36 \\
\hline L-isoleucine & 1.09 & 1.09 & 1.09 & 1.09 & 1.09 \\
\hline L-valine & 0.82 & 0.82 & 0.82 & 0.82 & 0.82 \\
\hline Soybean oil & 35.00 & 34.98 & 34.95 & 34.93 & 34.90 \\
\hline L-glutamate & 1.03 & 0.77 & 0.52 & 0.26 & 0.00 \\
\hline L-tryptophan & 0.00 & 0.17 & 0.35 & 0.52 & 0.69 \\
\hline Antioxidant ${ }^{3}$ & 0.01 & 0.01 & 0.01 & 0.01 & 0.01 \\
\hline Inert & 0.00 & 0.11 & 0.21 & 0.32 & 0.44 \\
\hline Total & 1000.00 & 1000.00 & 1000.00 & 1000.00 & 1000.00 \\
\hline \multicolumn{6}{|l|}{ Calculated composition } \\
\hline Crude protein, $\mathrm{g} / \mathrm{kg}$ & 157.3 & 157.3 & 157.3 & 157.3 & 157.3 \\
\hline Calcium, $\mathrm{g} / \mathrm{kg}$ & 40.2 & 40.2 & 40.2 & 40.2 & 40.2 \\
\hline Available phosphorus, $\mathrm{g} / \mathrm{kg}$ & 3.75 & 3.75 & 3.75 & 3.75 & 3.75 \\
\hline Metabolizable energy, $\mathrm{kcal} / \mathrm{kg}$ & 2,900 & 2,900 & 2,900 & 2,900 & 2,900 \\
\hline Digestible isoleucine, $\mathrm{g} / \mathrm{kg}$ & 6.61 & 6.61 & 6.61 & 6.61 & 6.61 \\
\hline Digestible lysine, $\mathrm{g} / \mathrm{kg}$ & 7.96 & 7.96 & 7.96 & 7.96 & 7.96 \\
\hline Digestible methionine, $\mathrm{g} / \mathrm{kg}$ & 4.97 & 4.97 & 4.97 & 4.97 & 4.97 \\
\hline
\end{tabular}

${ }^{1}$ Vitamin premix per kg of feed: vit. A - 15,000,000 IU; vit. D3 - 1,500,000 IU; vit. E - 15,000 U1; vit. B1 - 2.0 g; vit. B2 - 4.0 g; vit. B6 - 3.0 g; vit. B12 - 0.015 g; nicotinic acid - $25 \mathrm{~g}$; pantothenic acid - $10 \mathrm{~g}$; vit. $\mathrm{K} 3-3.0 \mathrm{~g}$; folic acid - $1.0 \mathrm{~g}$.

${ }^{2}$ Mineral premix per kg of feed: Mn - 60 g; Fe - 80 g; Zn - 50 g; Cu - 10 g; Co - 2 g; I - 1 g; selenium - 250 mg; excipient q.s. - 500 g.

${ }^{3}$ Butylated hydroxytoluene (BHT). 
The evaluation period of egg production was divided into five periods of 28 days. At the end of each period, the feed leftovers were collected from each plot for the calculation of feed intake. The collection of eggs was performed twice a day (10h00 and 16h00), and the frequency of laying and mortality rate were recorded in forms. The percentage of egg production was calculated by dividing the quantity of eggs totalized by plot by the number of birds, correcting that number by the mortality, whenever appropriate.

The eggs from the last three days of each period were weighed individually to obtain the average weight of the eggs. The calculations of egg mass were performed from the product of the egg production and the average weight of the eggs per plot. The feed conversion per egg mass was calculated from the ratio between the feed intake and egg mass produced. The conversion per egg dozen was calculated from the ratio between the feed intake divided by production, and this result was then multiplied by twelve.

At the end of each period, four eggs per plot were selected to determine weight and percentage of yolk, of albumen and of shell, after manual separation of these components. The shells were then placed in an oven at $105{ }^{\circ} \mathrm{C}$ for four hours. The percentage of each one of the components of the egg was obtained by dividing the weight of the component by the weight of the egg, and then the result was multiplied by 100 . Shell thickness was measured at three points along the midline of the egg with the aid of a digital micrometer with precision of $0.1 \mathrm{~mm}$, and with those measurements, the arithmetic mean was calculated.

At the end of each experimental period, representative samples were selected from two eggs per plot. These eggs were immersed in different saline solutions with the due adjustments for a volume of 25 liters of water with densities that varied from 1.060 to 1.100 with an interval of 0.0025 $\mathrm{g} / \mathrm{cm}^{3}$. The eggs were put in basins with the solutions, from lower to higher density and taken out when they began to float. The respective values of the densities corresponding to the solutions in the basins were then recorded. Before each evaluation, the densities were verified with a petroleum hydrometer.

For the histological analyses, the collection of the material was performed from fragments of the digestive system (duodenum and liver) and reproductive system (magnum and uterus) of 10 animals per treatment. The fragments were immersed in fixative methacarn $(60 \%$ methanol, $30 \%$ chloroform and $10 \%$ acetic acid) for 12 hours, and then transferred to $70 \%$ alcohol (Puchtler et al., 1970).

For the optical microscopy, the fragments were included in paraplast. Serial sections were performed on the fragments with $5 \mu \mathrm{m}$ thickness. The following histological stains were given for the histological description: hematoxylin and eosin, periodic acid Schiff (PAS) and Masson's trichrome. The photomicrographs were captured with the aid of a micro-camera attached to an Olympus BX-51 microscope and the images were digitalized on software KS 400.3 (Zeiss). Instestine (Figure 1), magnum (Figure 2A, B) and uterus (Figure 3): hematoxylin-eosin; magnum (Figure 2C, D): periodic acid Schiff; uterus (Figure 4): Masson's trichrome. Bar. uterus (Figure 3) - $50 \mu \mathrm{m}$; intestine (Figure 1) and magnun (Figure 2C, D) - $100 \mu$ m; magnum (Figure 2A, B) and uterus (Figure 4) - $500 \mu \mathrm{m}$.

Statistical analysis was conducted using the computational package SAEG (System for Statistical and Genetics Analysis, version 8.0), and the digestible tryptophan:lysine ratio requirement was established by linear and quadratic regression models.

\section{Results}

The variation in the ratio of digestible tryptophan: digestible lysine influenced the performance of the white laying hens (Table 2). The feed intake was not statistically modified $(\mathrm{P}>0.05)$; however, the other items evaluated (Table 2) had a significant effect, with a quadratic behavior

Table 2 - Effects of digestible tryptophan:digestible lysine ratio on performance of layers

\begin{tabular}{|c|c|c|c|c|c|c|}
\hline Tryptophan:lysine (\%) & FI & PR & EW & EM & CEM & $\mathrm{CDZ}$ \\
\hline 19 & 104.19 & 92.60 & 60.90 & 56.30 & 1.86 & 1.35 \\
\hline 21 & 104.58 & 94.44 & 62.71 & 59.20 & 1.77 & 1.33 \\
\hline 23 & 104.85 & 96.36 & 63.20 & 60.90 & 1.72 & 1.31 \\
\hline 25 & 106.11 & 96.95 & 63.63 & 61.69 & 1.72 & 1.31 \\
\hline 27 & 105.33 & 94.64 & 62.64 & 59.25 & 1.78 & 1.34 \\
\hline \multicolumn{7}{|l|}{$P$ value } \\
\hline Linear & 0.078 & 0.052 & 0.236 & 0.091 & 0.049 & 0.076 \\
\hline Quadratic & 0.123 & 0.003 & 0.004 & 0.035 & 0.028 & 0.037 \\
\hline Recommendation & - & 23.98 & 24.07 & 24.11 & 24.58 & 25.25 \\
\hline SEM & 0.459 & 0.426 & 0.552 & 0.536 & 0.016 & 0.008 \\
\hline
\end{tabular}

SEM - standard error of the mean; FI - feed intake (g); PR - egg production (egg/bird/day $\times 100)$; EW - egg weight (g); EM - egg mass (g); CEM - egg conversion in mass (g/g); $\mathrm{CDZ}$ - egg conversion in egg dozens $(\mathrm{g} / \mathrm{g})$. 
(egg production and egg weight at $\mathrm{P}<0.01$; egg mass, egg conversion in mass and egg conversion in egg dozens at $\mathrm{P}<0.05$ ).

After the derivations of the polynomial equations were obtained by the effects of the variables, the due recommendations were obtained, that is, the point of maximum or of minimum, considering the variable evaluated. The egg production presented a better index with a ratio of digestible tryptophan:digestible lysine at $23.98 \%$, according to the equation $\hat{\mathrm{Y}}=-2.297+8.250 \mathrm{x}$ $-0.172 \mathrm{x}^{2} / \mathrm{R}^{2}=0.93$. Weight, mass, conversion in mass and in egg dozens provided derivatives of $24.07 ; 24.11 ; 24.58$; and 25.25 , according to the equations $\hat{\mathrm{Y}}=4.973+$ $4.863 \mathrm{x}-0.101 \mathrm{x}^{2} / \mathrm{R}^{2}=0.98 ; \hat{\mathrm{Y}}=-57.94+9.933 \mathrm{x}-0.206 \mathrm{x}^{2} /$ $\mathrm{R}^{2}=0.97 ; \hat{\mathrm{Y}}=5.223-0.295 \mathrm{x}+0.006 \mathrm{x}^{2} / \mathrm{R}^{2}=0.99 ;$ and $\hat{Y}=2.509-0.101 \mathrm{x}+0.002 \mathrm{x}^{2} / \mathrm{R}^{2}=0.95$, respectively.

Although there was no statistical effect on specific gravity $(\mathrm{P}>0.05)$ by the variation in the ratios utilized, the absolute weights of the albumen, shell and yolk, and the relative weights of the shell and yolk were affected (Table 3).

The egg quality variables (Table 3 ) with a significant effect had a quadratic behavior, in which the equations: $\hat{Y}=15.67+1.786 x-0.037 x^{2} / R^{2}=0.73 ; Y=-13.40+1.793 x$ $-0.037 \mathrm{x}^{2} / \mathrm{R}^{2}=0.83 ; \hat{\mathrm{Y}}=-44.12+5.013 \mathrm{x}-0.105 \mathrm{x}^{2} /$ $\mathrm{R}^{2}=0.75 ; \mathrm{Y}=-2.781+1.182 \mathrm{x}-0.024 \mathrm{x}^{2} / \mathrm{R}^{2}=0.98$; and $\hat{\mathrm{Y}}=$ $-27.98+4.144 \mathrm{x}-0.086 \mathrm{x}^{2} / \mathrm{R}^{2}=0.80$ provided derivatives of $24.13 ; 24.23 ; 23.87 ; 24.63$; and 24.09 , for the absolute weights of the albumen, shell and yolk, and relative weights of the shell and yolk, respectively.

Histologically, alterations were verified in some organs of the reproductive and digestive systems of laying hens because the diets contained a higher ratio of digestible tryptophan: digestible lysine (23, 25 and 27\%). The intestinal villi of the laying hens under diets with a higher ratio were wider and had more branches (Figure 1A, B). No alteration was observed in the quantity or in the production of intestinal goblet cells. The folds of the magnum in these groups had more branches with more active glands (Figure 1C, D). The epithelium of these folds produced more mucus (Figure 1E, F). The uterus of the laying hens in these groups had more secondary folds (Figure I, J). The epithelium of these uteruses had hyperplasia (Figure 1G, H).

With the increase of the tryptophan:lysine ratio in the diet, there was also an increase in hepatic steatosis (Figure $2 \mathrm{~A}, \mathrm{~B})$. In the group in which the birds were subjected to a diet in which the ratio was $27 \%$, hepatic steatosis was evident (Figure 2B, D), although some birds did not show this characteristic so evidently. In the groups in which the ratio was higher, a small quantity of parenchymal collagen was also found (Figure 2D). This parenchymal collagen was not found in the groups with a lower ratio of tryptophan: lysine (groups with ratio of 19 and 21\%) (Figure 2C). In the group with a tryptophan:lysine ratio of $27 \%$, there was also a higher positivity for histological PAS (Periodic Acid Schiff) staining, showing a higher deposit of glycogen (Figure 2E, F).

\section{Discussions}

Amino acids are very similar chemical structures and, in some cases, they dispute for the same absorption site, generating what is known as amino acid antagonism. In this context, Peganova \& Eder (2003), comment that the excess of isoleucine can compromise the passage of tryptophan through the blood-brain barrier, provoking a deficiency of this amino acid in the brain, which can influence the synthesis or liberation of serotonin. These authors also verified that the increase in the levels of tryptophan from 1.5 to $2.4 \mathrm{~g} / \mathrm{kg}$ resulted in an increase in feed intake, although without effect on the plasmatic levels of tryptophan or on the egg mass produced.

Unlike what was observed by Peganova \& Eder (2003), in this study, no effect was observed on feed intake. The difference between these results and those in the study of the authors cited above can occur from the maintenance of

Table 3 - Effects of digestible tryptophan:digestible lysine ratio on egg quality of layers

\begin{tabular}{|c|c|c|c|c|c|c|c|}
\hline Tryptophan:Lysine (\%) & $\mathrm{SG}$ & Alb & Shell & Yolk & Walb & Wshell & Wyolk \\
\hline 19 & 1.087 & 36.00 & 7.21 & 13.36 & 43.81 & 10.73 & 19.74 \\
\hline 21 & 1.086 & 36.73 & 7.69 & 14.27 & 44.10 & 11.19 & 20.43 \\
\hline 23 & 1.086 & 36.56 & 7.89 & 15.14 & 45.35 & 11.28 & 21.41 \\
\hline 25 & 1.079 & 37.03 & 8.30 & 16.21 & 46.56 & 11.31 & 22.12 \\
\hline 27 & 1.086 & 36.39 & 7.63 & 14.07 & 44.99 & 11.11 & 20.52 \\
\hline \multicolumn{8}{|l|}{$P$ value } \\
\hline Linear & 0.326 & 0.072 & 0.045 & 0.123 & 0.172 & 0.213 & 0.069 \\
\hline Quadratic & 0.472 & 0.042 & 0.039 & 0.032 & 0.231 & 0.031 & 0.029 \\
\hline Recommendation & - & 24.13 & 24.23 & 23.87 & - & 24.63 & 24.09 \\
\hline SEM & 0.001 & 0.291 & 0.172 & 0.315 & 0.543 & 0.164 & 0.301 \\
\hline
\end{tabular}

SEM - standard error of mean; SG - specific gravity $\left(\mathrm{g} / \mathrm{cm}^{3}\right)$; Alb - absolute weight of the albumen ( $)$; Walb - relative weight of the albumen (\%); Shell - absolute weight of the shell (g); Wshell - relative weight of the shell (\%); Yolk - absolute weight of the yolk (g); Wyolk - relative weight of the yolk (\%). 


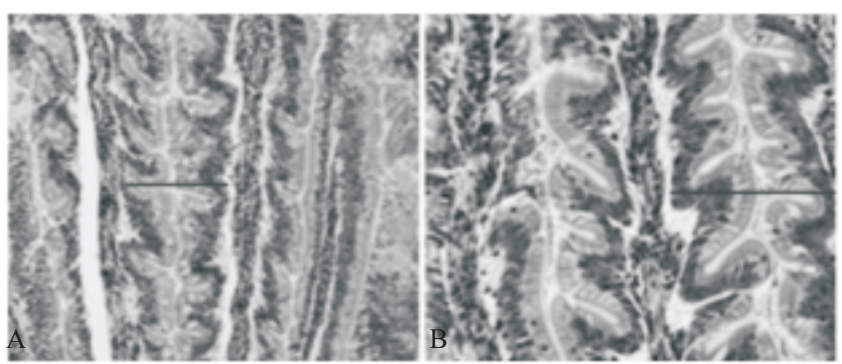

A and B: Notice the greater width (dotted line) of the intestinal villi with the increase of the tryptophan: lysine ratio.

Figure 1 - Intestine of laying hens subjected to diets with digestible tryptophan:digestible lysine ratios of $19 \%$ (A) and above $23 \%$ (B).
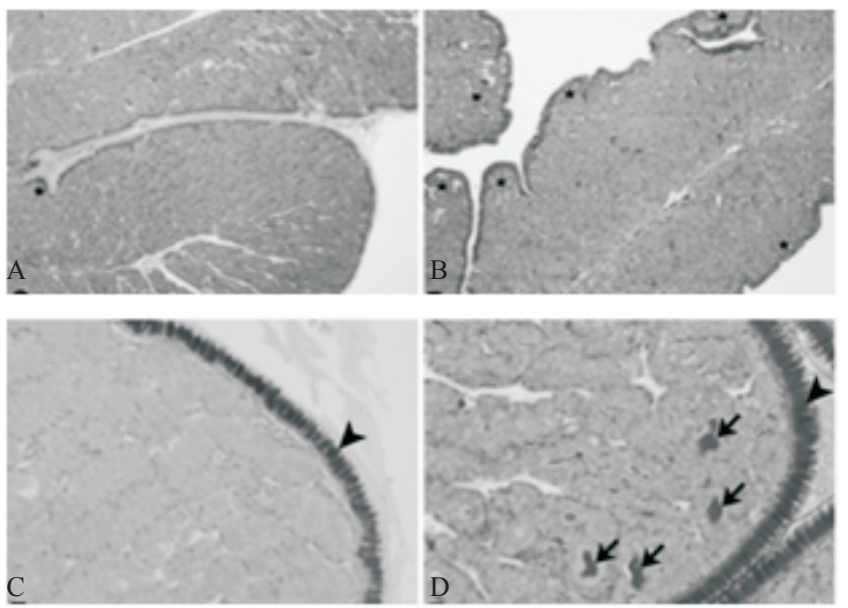

A and B: Notice the higher incidence of secondary folds (star) with the increase of the tryptophan:lysine ratio. $\mathrm{C}$ and $\mathrm{D}$ : Notice the greater production of mucus by the epithelial cells (tip of the arrow) and greater activity of the glands of the magnum (production of albumen) (arrow)

Figure 2 - Magnum of laying hens subjected to diets with digestible tryptophan:digestible lysine ratios of $19 \%(\mathrm{~A} ; \mathrm{C})$ and $23 \%(\mathrm{~B} ; \mathrm{D})$.

the crude protein and metabolizable energy levels in the experimental diets, with only tryptophan varying, while in the study of Peganova \& Eder (2003) such levels are not balanced due the supplementation of L-tryptophan in the feed.

In an evaluation of the ideal level of tryptophan in the feed of laying hens at 28 weeks of age, Harms \& Russel (2000) utilized increasing levels of tryptophan $(1.2 ; 1.3 ; 1.4$; $1.5 ; 1.6 ; 1.7 ; 1.8 ;$ and $2.0 \mathrm{~g} / \mathrm{kg}$ ). In that study, the production and the weight of the eggs increased with the elevation of the levels of tryptophan. Furthermore, the birds showed a reduction in the live weight at the end of the study with lower levels of tryptophan $(1.2,1.3$ and $1.4 \mathrm{~g} / \mathrm{kg})$, while in the other treatments, with higher levels of this amino acid, the birds maintained or even gained weight.

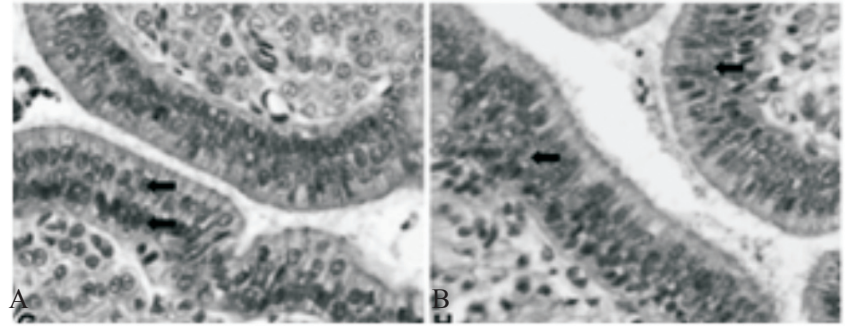

Notice that in A the epithelium has its layers of cells (arrows). And the epithelium of the uterus in the groups with a higher tryptophan:lysine ratio B, have more than two cellular layers (arrow).

Figure 3 - Epithelium of the uterus of laying hens subjected to diets with digestible tryptophan:digestible lysine ratios of $19 \%$ (A) and above $23 \%$ (B).

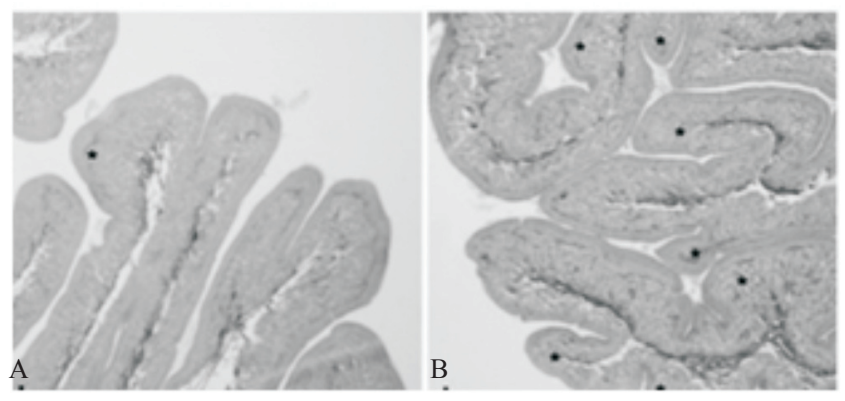

Notice that with the increase of the tryptophan:lysine ratio, the number of secondary folds increases (star)

Figure 4 - Folds of the uterus of laying hens subjected to diets with digestible tryptophan:digestible lysine ratios of $19 \%$ (A) and above 23\% (B).

According to the data, tryptophan significantly improved the performance of the birds evaluated by the authors, to the point of egg production going from 66.20 to $92.70 \%$ in the birds that consumed feed with 1.2 and $1.7 \mathrm{~g} / \mathrm{kg}$ tryptophan, respectively. Besides egg production, the weight of the eggs also had an expressive increase, from 49.70 to $54.80 \mathrm{~g}$ when the birds consumed feed with 1.2 and $2.0 \mathrm{~g} / \mathrm{kg}$ tryptophan, respectively. For this variable, the authors estimated a dietetary requirement of $1.85 \mathrm{~g} / \mathrm{kg}$ tryptophan through broken-line regression.

The increase of digestible tryptophan in the feed of the birds evaluated in this study improved the production and the quality of the eggs, as also observed by Harms \& Russel (2000) (Tables 2 and 3). Although the feed intake was not influenced, and with the improvement in the production and weight of the eggs, the variables that are obtained from these variables, such as conversion in mass and in egg dozens, were sequentially improved. 


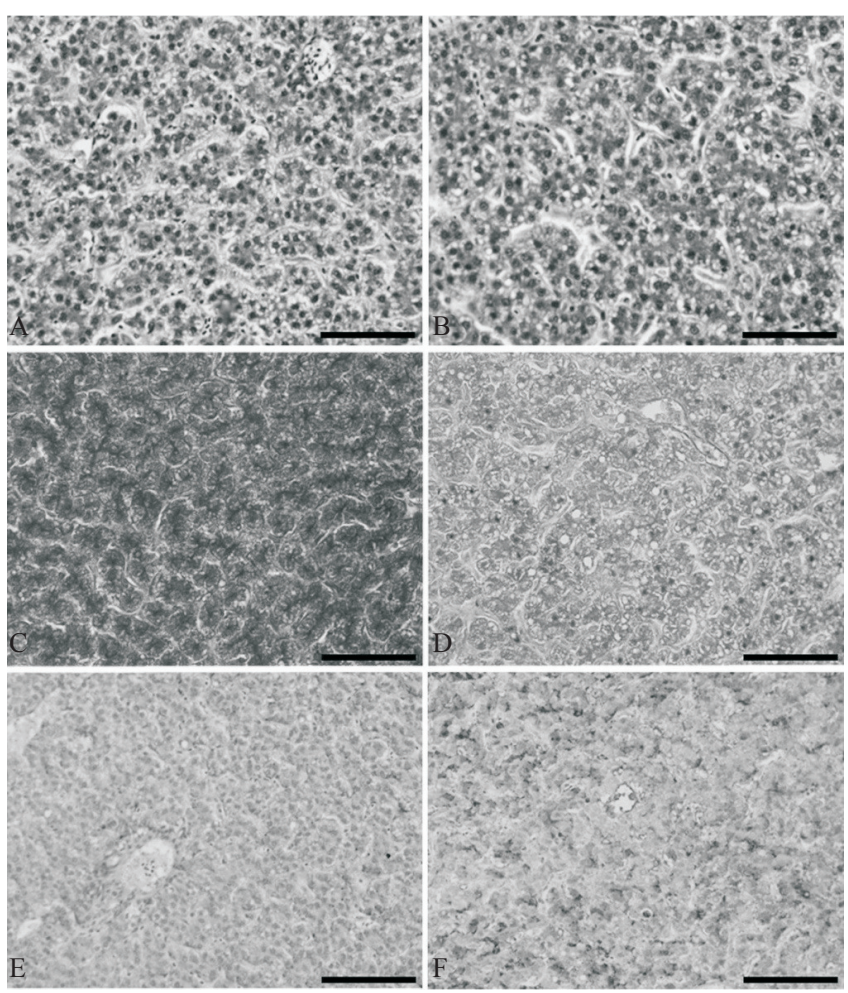

A, C and E: tryptophan:lysine ratio of $19 \%$.

B, D and F: tryptophan:lysine ratio of $27 \%$. In this group, the liver had hepatocytes with cytoplasmic lipid vacuoles, an indication of steatosis (B and D). There was also a deposit of parenchymal collagen, represented by a bluish color on Masson's trichrome (D) and an accumulation of hepatic glycogen represented by a dark gray color on the periodic acid Schiff (PAS) (F).

A, B: hematoxylin-eosin; C, D: Masson's trichrome; E, F: PAS. Bar: $100 \mu \mathrm{m}$.

Figure 5 - Liver of laying hens subjected to diets with different ratios of digestible tryptophan:digestible lysine.

Deponti et al. (2007) obtained similar results to those found in this study when working with laying hens during the laying phase. These authors verified that production and egg mass were negatively affected during six weeks, when laying hens received diets with low levels of tryptophan $(1.3 \mathrm{~g} / \mathrm{kg})$, and that the performance was recovered after a week receiving feed containing tryptophan at $2.1 \mathrm{~g} / \mathrm{kg}$. The results from the present study also corroborate those found by Harms \& Russell (2000), who found worse performance of birds with lower levels of tryptophan in their diets.

Bregedahl et al. (2008), in a series of experiments with white laying hens at 28 to 34 weeks, determined that the ideal ratio of digestible tryptophan:digestible lysine was 22 , corresponding to a daily intake of $538 \mathrm{mg}$ of lysine and $120 \mathrm{mg}$ of tryptophan. In the present study, in the average of the recommendations, from the data of performance and external and internal quality of the eggs, a digestible tryptophan:digestible lysine ratio of $24 \%$ was the one that yielded the best results.

In a trial by Costa et al. (2010), also with white laying hens, using tryptophan:digestible lysine ratios varying from 19 to $27 \%$, a quadratic response for all of the variables evaluated was shown, except for feed intake. Costa et al. (2010) concluded that the tryptophan:digestible lysine ratio of $24 \%$ was sufficient for better performance of the birds, which was confirmed in this study and in the recommendations made by Bregendahl et al. (2008).

Although some data in the literature cite only the effects of the supplementation of tryptophan in the feed on animal performance, the results herein presented reconcile these data with histological modifications in the digestive and reproductive tract of laying hens, which gives greater support to the results obtained.

Histologically, the increase in the digestible tryptophan: digestible lysine ratio provoked a greater production of albumen by the magnum, since the tubular glands of the magnum were found to be in a more active functional stage and had a greater quantity of albumen, which permits the production of eggs to be achieved in a shorter period of time, thus increasing production, weight, mass, conversion in mass and egg dozens, corroborating the results obtained and shown in this study.

Still in relation to the magnum, a larger production of mucus in the epithelium of this organ was observed. This characteristic enables the egg to get through the oviduct faster (Gomide-Júnior et al., 2004). Likewise, the increase of digestible tryptophan:digestible lysine ratio also elevated the quantity of secondary folds in the uterus of the white laying hens in production stage and generated hyperplasia of the uterus epithelium. Such characteristics permit the formation of the shell in a shorter time, thus increasing egg production, since the egg being formed stays in the uterus for variable time for the deposition of calcium carbonate (King \& McLelland, 1979), and this is accelerated by the increase of internal surface of the organ.

The better performance of the birds in relation to a higher supplementation of tryptophan in their feed can also be explained by the histological alterations found in the intestinal villi of the birds in the treatments receiving feed with higher ratios of digestible tryptophan:digestible lysine $(23,25$ and $27 \%)$. In those, the villi were larger and more branched. This re-arrangement of the mucosa demonstrates the physiological need to enlarge the absorptive surface of the small intestine in relation to a certain nutrient (Aptekmann et al., 2001), in this case, tryptophan. These facts corroborate the results of Gomide-Júnior et al. (2004), which demonstrate that the intestinal mucosa responds to exogenous agents by means of morphologic modifications in the height and number of intestinal villus, depth of intestinal crypts, cell proliferation and number of dead cells by epithelial loss. 
In relation to steatosis aggravation with the increase of the digestible tryptophan:digestible lysine ratio in the feed, studies demonstrate that supplementing the feed with methionine also induces the increase of hepatic fat (Bunchasak \& Taweesak, 2005). This increase in hepatic steatosis can be caused by a higher synthesis of estrogen in the ovary to give support to the higher egg production (Bunchasak \& Taweesak, 2005), which is contrary to the results from this study.

In relation to the small deposits of parenchymal collagen observed in the liver of the birds with the increase in the ratio of digestible tryptophan:digestible lysine in their feed, it may be pointed out that, although in small quantity, this effect shows fibrotic process resulting from continuous processes of hepatocyte regeneration (Fausto, 2003). However, because the productive life of a laying hen is short, such metabolic alteration does not generate productive, quality and consequently, economical losses.

The treatment which more evidently showed this hepatic alteration, as well as greater steatosis, was the one with a digestible tryptophan:digestible lysine ratio of $27 \%$, a ratio which did not show the best animal performance results. The higher accumulation of glycogen in the livers (higher positivity to PAS staining) of the birds in the treatment with a ratio of digestible tryptophan:digestible lysine at $27 \%$ can be due to the presence of parenchymal collagen deposits which hinder the flow of glycogen, as well as of other nutrients through the centrilobular veins of the hepatic lobes.

The results of this study show that the ideal digestible tryptophan:digestible lysine ratio is higher than that recommended by the NRC (1994), by the CVB (1996), by Coon \& Zhang (1999), Rostagno et al. (2005), Rostagno et al. (2011), Leeson \& Summers (2005) and Brengendahl et al. (2008), since their recommendations are of ratios of 23,19 , 20, 23, 23, 21 and 22, respectively.

In the present study, requirements were calculated using derivatives of the quadratic functions. This is one of the valid methods currently used to calculate requirements. Perhaps it is not the most used, but it is accepted (Tillman, 2011).

In a paper recently presented by Tillman (2011), they compare, using a same data set, the requirement estimations with different mathematical approaches. It could be concluded that the derivative alone leads to a value that is 5 to $10 \%$ higher than when requirements are calculated using broken line analysis. Thus, the recommendations can be higher because of the method used to obtain requirements, polynomial regressions.

\section{Conclusions}

Increase in the digestible tryptophan:digestible lysine ratio causes significant effects on the digestive and reproductive systems of white laying hens in the productive stage with an increase in the animal performance indexes, and in accordance with the average of determinations of the best value, the ratio of $24.5 \%$ promotes the best indexes.

\section{Acknowledgments}

Special thanks to CNPq (process $n^{\circ} 141196 / 2009-2$ ), Granja Planalto and Ajinomoto Animal Nutrition.

\section{References}

AJINOMOTO. Lisina Cristal. Ajinomoto Animal Nutrition. 2010. Available at: <htpp://www.lisina.com.br/lisina_cristal.aspx $>$. Accessed on: July 10, 2011.

APTEKMANN, K.P.; BARALDI-ARTONI, S.M.; STEFANINI, M.A. et al. Morphometric analysis of the intestine of domestic quails (Coturnix coturnix japonica) treated with different levels of dietary calcium. Anatomia, Histologia, y Embryologia, v.30, n.5, p.277-280, 2001.

BREGENDAHL, K.; ROBERTS, S.A.; KERR, B. Ideal ratio of isoleucine, methionine, methionine plus cystine, threonine, tryptophan, and valine relative to lysine for white leghorn-type laying hens of twenty-eight to thirty-four weeks of age. Poultry Science, v.87, p.744-758, 2008.

BUNCHASAK, C.; SILAPASORN, T. Effects of adding methionine in low-protein diet on production performance, reproductive organs and chemical liver composition of laying hens under tropical conditions. International Journal of Poultry Science, v.4, n.5, p.301-308, 2005.

CENTRAAL VEEVOEDERBUREAU - CVB. Aminozurenbehoefte van leghennen en vleeskuikens [Amino acid requirements for laying hens and broiler chickens]. Documentation Report nr. 18 (in Dutch). Lelystad, the Netherlands: Centraal Veevoederbureau, 1996. 56p.

COON, C.; ZHANG, B. Ideal amino acid profile for layers examined. Feedstuffs, v.71, n.14, p.13-15, 1999

COSTA, F.G.P.; LIMA, M.R.; SÁ, L.M. et al. Relação triptofano digestível: lisina digestível sobre o desempenho de poedeiras leves. In: REUNIÃO ANUAL DA SOCIEDADE BRASILEIRA DE ZOOTECNIA, 47., 2010, Salvador. Anais... Salvador: SBZ, 2010.3p.

DEPONTI, B.J.; FARIA, D.E.; FARIA FILHO, D.E. Exigências de triptofano e padrão de recuperação do desempenho de poedeiras comerciais após alimentação com rações deficientes em triptofano. Revista Brasileira de Zootecnia, v.36, n.5, p.1324-1330, 2007.

FAUSTO, N. New perspectives on liver regeneration. Hepatology, v.6, n.2, p.326-327, 2003.

GOMIDE - JUNIOR, M.L; STERZO, E.V.; MACARI, M. et al. Use of scanning electron microscopy for the evaluation of intestinal epithelium integrity. Revista Brasileira de Zootecnia, v.33, n.6, p.1500-1505, 2004.

HARMS, R.H.; RUSSEL, G.B. Evaluation of tryptophan requirement of the commercial layer by using a corn-soybean meal basal diet. Poultry Science, v.79, p.740-742, 2000.

KING A.S.; MCLELLAND, J. Form and function in birds. London: Academic Press, 1979. 493p.

LEESON, S.; SUMMERS, J.D. Commercial poultry production. 3.ed. Guelph: University Books, 2005. 236p. 
NUTRIENT RESEARCH COUNCIL - NRC. Nutrient requirements of poultry. 9.ed. Washington, D.C.: National Academics Press, 1994. 176p.

PEGANOVA, S.; EDER, K. Studies on requirement and excess of isoleucine in laying diets. Poultry Science, v.81, p.1714-1721, 2002.

PEGANOVA, S.; EDER, K. Interactions of various supplies of isoleucine, valine, leucine and tryptophan on the performance of laying hens. Poultry Science, v.82, p.100-105, 2003.

PUCHTLER, H.; WALDROP, F.S.; MELOAN, M.S. et al. Histochemie. 27.ed. Heidelberg: Springer Berlin, 1970. 97p.
ROSTAGNO, H.S.; ALBINO, L.F.T.; DONZELE, J.L. et al. Tabelas brasileiras para aves e suínos: composição de alimentos e exigências nutricionais. Viçosa, MG: Universidade Federal de Viçosa, 2011. 252p.

ROSTAGNO, H.S.; ALBINO, L.F.T.; DONZELE, J.L. et al. Tabelas brasileiras para aves e suínos: composição de alimentos e exigências nutricionais. 2.ed. Viçosa, MG: UFV/DZO, 2005. 186p.

TILLMAN, P.B. Special considerations for amino acids in broiler nutrition. In: INTERNATIONAL SYMPOSIUM ON NUTRITIONAL REQUIREMENTS OF POULTRY AND SWINE, 3., 2011, Viçosa, MG. Anais... Viçosa, MG, 2011. 24p. 